\title{
Consideration of Environmental Effect of Power Generation: Bangladesh Perspective
}

\author{
Iftekhar Zaman Arnab, Tausif Ali, M. Shidujaman, Md. Mayen Hossain \\ Dept. of Electrical and Electronic Engineering, American International University-Bangladesh, Dhaka, Bangladesh \\ Email: iz.arnab@gmail.com, tau9097@gmail.com
}

Received 2013

\begin{abstract}
Nowadays for power generation, environment is a major consideration. The heart of power generation is power station. At present there are almost above 40(Both Government \& Rental) power station in Bangladesh. Among these $80 \%$ of power station is gas based. Rest of the $20 \%$ is coal, liquid and furnace oil based. Bangladesh has only one Hydraulic power station. These gas and coal based power stations are giving adverse effect in Bangladesh. The main emissions from coal combustion at thermal power plants are carbon dioxide (CO), nitrogen oxides (NO), sulfur oxides (SO), chlorofluorocarbons (CFCs), and air- borne inorganic particles such as fly ash, soot, and other trace gas species. Carbon dioxide, methane, and chlorofluorocarbons are greenhouse gases. These emissions are considered to be responsible for heating up the atmosphere, producing a harmful global environment. It is known to all that hydro power station is a clean source of energy, but it has also some ecological and environmental effect. Dhaka is one of the top polluted city in the world. So for power generation if the environmental effect is not considered then Bangladesh will be in great trouble. The purpose of this paper is to discuss the present and future possible environmental effect of power generation in Bangladesh.
\end{abstract}

Keywords: Environment; Pollution; Power Generation; Air pollution; Water Pollution; Thermal Pollution; Acid Rain; Renewable Energy; Nuclear Power Plant

\section{Introduction}

Bangladesh is a developing country [1].But Bangladesh's energy infrastructure is quite small, insufficient and poorly managed [2] .So Bangladesh is facing huge load shedding of electricity. In Bangladesh electricity power is not generating as much as our demand. According to the official statistics, the country's electricity shortage gone up 1000 megawatts (MW) to 1259 MW [3].So Bangladesh aims to develop the indigenous energy resources which play a vital role in the socio-economic development of the country. Government has declared its vision to make electricity available for all by 2020 . To fulfill this vision, Government plans to increase power generation [4]. The production and consumption of electricity lead to environmental impacts [5]. One of the major concerns now-a-days is global warming. Global warming or the greenhouse effect is an environmental issue that deals with the potential for global climate change due to increased levels of atmospheric greenhouse gases. This means that when combusted, coal and oil release higher levels of harmful emissions, including a higher ratio of carbon emissions, nitrogen oxides $\left(\mathrm{NO}_{\mathrm{x}}\right)$, and sulfur dioxide $\left(\mathrm{SO}_{2}\right)$. Coal and fuel oil also release ash particles into the environment, substances that do not burn but instead are carried into the atmosphere and contribute to pollution [6]. And most electricity is generated by power plants using non-renewable fossil fuels like coal, oil and natural gas. Most scientists agree that this is causing global warming. The electricity industry had thereby become deeply enmeshed in most of the leading environmental problems of concern to both Governments and citizens. Almost all major forms of electricity generations-fossil fuel based, nuclear, large hydro, newer renewable, as well as transmission have raised serious environmental concern [7]. The environment is greatly harmed by the process of power generation. This paper evaluates the Environmental effect of power generation with respect to Bangladesh.

\section{Thermal Pollution}

The most effective pollution in Bangladesh is thermal pollution. Thermal Pollution occurs because of the thermal power plants, nuclear power plants, fossil fuel like coal, natural gas, oil etc. A large number of heats are rejected to the environment every day from these power plants. Degradation of water quality by any process that changes water temperature is Thermal pollution. A common cause of thermal pollution in Bangladesh is the 
use of water as a coolant by power plants. When water used as a coolant is returned to the natural environment at a higher temperature, the change in temperature decreases oxygen supply, and affects ecosystem composition. If the temperature of water is largely increased then it can denature the life-supporting enzymes by breaking down hydrogen and disulphide bonds within the quaternary structure of the enzymes. Sometime this water as coolant can be taken from natural or artificial resources. Now when a power plant first opens or shuts down for repair or other causes, fish and other organisms in those water resources adapted to particular temperature range can be killed by the abrupt change in water temperature known as "thermal shock". This thermal shock causes every year lots of fishes die. Since most of the thermal power plants are situated besides the main rivers of Bangladesh. Again, Releases of unnaturally cold water from artificial resources can dramatically change the fish and macro invertebrate fauna of rivers, and reduce river productivity. Also, due to the sudden fall of water temperature the contraction on dam and bridge pylon may take place which may cause harmful effect in Bangladesh.

Bangladesh has only one coal power station. Coals have an adverse effect on the environment. It generates hundreds of millions of tons of waste products, including fly ash, bottom ash, and flue gas desulphurization sludge. This waste disposal is a great burden for Bangladesh. Coal interferes with groundwater and water table levels and impact of water use on flows of rivers and consequential impact on other land-uses. Also release of carbon dioxide, a greenhouse gas, which causes climate change and global warming and Bangladesh is being adversely affected by this global warming.

Pollution of air in Bangladesh is the most significant environmental pollution. Air pollution from coal-fired power plants is huge and contributes to a negative environmental and health effects. When coal is burned to generate electricity, the combustion releases a combination of toxic chemicals into the environment. Its combustion releases nitrogen oxides, sulfur dioxide, particulate matter (PM), mercury, and dozens of other substances known to be hazardous to environment. Carbon dioxide is a big component of air pollution. It is responsible for Global warming. The dangers of global warming include disruption of Bangladesh weather patterns and ecosystems, flooding, severe storms, and droughts. A warming climate will also extend the range of infectious diseases. That is why people living besides power stations are affected mostly.

\section{Prepare Your Paper before Styling}

Bangladesh is not familiarized with acid rain. But for future environmental effect it is also considerable. Acid rain is a broad term used to describe several ways that acids fall out of the atmosphere. It represents mixing of environmental pollutants with the rain water. The mixing raises the acidity of rain water by formations of acids following chemical reactions involving pollutant gases and water. The major pollutants that cause acid rain are sulfur dioxide $\left(\mathrm{SO}_{2}\right)$ and nitrogen oxides $\left(\mathrm{NO}_{\mathrm{x}}\right)$ produced during the combustion of fossil fuels. When these gases are released into atmosphere after the combustion of fossil fuels, these gases accumulates in the atmosphere. After that the chemical reaction starts between the gases and the water vapors. The oxidation of the gases converts sulfur dioxide $\left(\mathrm{SO}_{2}\right)$ into sulfuric acid $\left(\mathrm{H}_{2} \mathrm{SO}_{4}\right)$ and nitrogen oxides $\left(\mathrm{NO}_{\mathrm{x}}\right)$ to nitric acid $\left(\mathrm{HNO}_{3}\right)$. When rain falls, these dissolved deposits are returned back to earth's surface in the form of acid rain. Most of these gases are released into atmosphere by the electrical utilities during combustion of coal. Electrical utilities contribute about $70 \%$ of sulfur dioxide $\left(\mathrm{SO}_{2}\right)$ and $30 \%$ of nitrogen oxides $\left(\mathrm{NO}_{\mathrm{x}}\right)$. The acidity of the acid rain is measured by its $\mathrm{pH}$. $\mathrm{pH}$ value is represented by a scale of 1-14. The lesser the $\mathrm{pH}$ value is, more acidic is the water. $\mathrm{PH}$ value 7 represents neutral solution i.e. neither acidic nor base. The $\mathrm{pH}$ of the non polluted rain lies between 5-5.6. The reason being the natural processes also emit these pollutant gases into the atmosphere. The $\mathrm{pH}$ of the acid rain may fall to 4.0 or even less depending on the intensity of pollution.

Already Bangladesh has only $10 \%$ of the forest. But at least $25 \%$ forest is required for any country. So from that view at present Bangladesh is really in trouble. Though there is yet not occurred acid rain in Bangladesh but acid rain may cause serious threat to forests. The pollutants get deposited on the surface of the plants and interfere with photosynthesis. This abruptly causes death of the plants. Acid deposition due to rainfall has the potential to affect sensitive forests. The other devastating effect of acidic deposition in the water bodies is the declining biodiversity in the lakes and ponds. Many marine species that are part of food chain can not survive below $\mathrm{pH}$ value of 6 . This further affects the other members of the food chain and the food chain is destroyed. As acidic water flows over and through the ground, it affects a variety of plants and animals. In addition, acid rain accelerates the decay of building materials and paints, including irreplaceable buildings, statues, and sculptures that are part of our nation's cultural heritage. Prior to falling to the earth, $\mathrm{SO}_{2}$ and $\mathrm{NO}_{\mathrm{x}}$ gases and their particulate matter derivatives, sulfates and nitrates, contribute to visibility degradation and harm public health.

\section{Renewable Energy}

In order to combat global warming and the other problems associated with the fossils fuels we are switching to renewable energies. Though Renewable energies are 
clean compared to the other forms of fuel, but it also effects the environment.

In Bangladesh, the renewable energy sector mainly consists of solar, wind and biomass energies. There are also some other sources like Hydroelectric, wind, wave, tidal, geothermal energy etc.

In case of solar energy annually about 1.9MWh energy is received per square meter of horizontal area in Bangladesh. But no air pollution during operation, the primary environmental, health, and safety issues involve how they are manufactured, installed, and ultimately disposed of. One of the concern is energy is required to manufacture and install solar components, and any fossil fuels used for this purpose will generate emissions and have an effect on environment. Beside large amount of land is needed for solar panels and in case of rainy season they will be useless. So lands are being wasted. Besides, solar panels generate large amount of heat. It effects the surrounding environment.

Wind energy is perhaps the cleanest form of energy. But it has also sum drawbacks. In Bangladesh Wind energy are being used in coastal areas. But the concerns over wind energy are the noise being created by wind turbine. There are claims that this system does not offer adequate safeguard. If the blades of wind turbine get cut of it can harm the surrounding areas. Bird dies due to the collision with blades of the turbine. To build structures large number of trees get cut off.

In Bangladesh only $230 \mathrm{MW}$ of hydropower is utilized. This comes from Karnafuli Hydro Station. Hydropower got negative environmental effect compared to other energy sources. The original Rangamati town, including the palace of the king, went into the lake created by the dam. Apart from uprooting thousands of people, the Kaptai project has also created other adverse impacts, such as: loss of forest resources (a staggering 75 kilometers of reserve forest area and another 600 square kilometers of unclassified forest areas went into the lake), decline in wildlife and cattle, scarcity of drinking water. Now, threatened by the silting up of Kaptai Lake due to deposition of soil from the surrounding hilly areas from massive deforestation and jhum cultivation (means paddy cultivation on the hill area). The lake is losing its navigability and water discharging capacity, as the silt deposited in the riverbed has not been removed since the beginning. On the other hand, the lake overflows its banks during the rainy season creating a flood like situation. These are some common but costly situation of hydropower that harms the surrounding environment greatly.

Bangladesh has very small scale biomass power plant. It derived from the burning of plant matter, raises more serious environmental issues than any other renewable resource except hydropower. Combustion of biomass and biomass-derived fuels produces air pollution; beyond this, there are concerns about the impacts of using land to grow energy crops. Emissions from conventional biomass-fueled power plants are generally similar to emissions from coal-fired power plants. So the effect it has on air is very adverse. Similar to coal fired plants it pollutes air and also aids to the global warming. Since a large amount of land is needed food production is minimized. A country like Bangladesh cannot afford to lose land like this. The burning of plant matter and other toxic chemical released from the stations effects surrounding environment. So for establishing large scale biomass power plant government should consider the possible future environmental effect.

Though Bangladesh is still now not going to geothermal power plant, but environmental concerns must be taken for future geothermal power plant. In case of geothermal energy resource types differ in many respects, but they raise a common set of environmental issues. Air and water pollution are two leading concerns, along with the safe disposal of hazardous waste, sitting, and land subsidence. The method used to convert geothermal steam or hot water to electricity directly affects the amount of waste generated. Open-loop systems can generate large amounts of solid wastes as well as noxious fumes. Metals, minerals, and gases leach out into the geothermal steam or hot water as it passes through the rocks. The large amounts of chemicals released when geothermal fields are tapped for commercial production can be hazardous or objectionable to people living and working nearby. Scrubbers reduce air emissions but produce a watery sludge high in sulfur and vanadium, a heavy metal that can be toxic in high concentrations.

Tidal and wave energy is also not available in Bangladesh. But this type of energy is knocking the future energy resources as Bangladesh has sufficient tidal height $(7-8 \mathrm{~m})$ in some areas. But this type of power plant has also some environmental problem. Tidal energy is a clean source of energy. But the construction of large dams to harness tidal energy causes ecological problems for the marine life. Also there is a chance of soil loses. Wave energy can be used to reduce harmful greenhouse effect. But the main negative impacts are visual intrusion and noise from air turbines. Near shore and offshore plants may constitute obstacles to coastal marine traffic and, when deployed in large numbers may promote modifications to coastal dynamics. Thus, wave energy devices situated offshore can have some impact on navigation. Other impacts, namely on ecosystems, on fishing and on recreation and tourism may occur.

\section{Possible Future Environmental Effect of Nuclear Power Plant}

Nuclear energy is a great source for electricity generation. Its mechanism is clean compared to the other fuels. Gov- 
ernment of Bangladesh had decided to implement the Rooppur Nuclear Power Plant Project. If installed its capacity will be around 400 to 600 Megawatt (MW). Though nuclear energy is clean compared to other fuels, but it still got widespread adverse effect on the environment.

The first fact to note is that operating a nuclear power plant is quite different from the operation of any other kind of power generating plant, and for that matter, any other kind of industrial facility. This is because of the devastating consequences the population may face if an accident occurs during the operation of a plant.

Before elaborating this point, it is necessary to describe, in brief, some special aspects of a nuclear power plant. A nuclear power plant uses turbines to generate electricity. These turbines are driven by steam or heated gas. In this respect, nuclear power plants are very similar to most of the other power plants. Where it differs from them is how the steam or heated gas is produced to turn the turbines. Typically, in a nuclear power plant, water or gas is heated by the heat energy produced by the fission reaction of radioactive uranium inside a container known as a reactor. A fission reaction is similar in kind to that taking place in an atomic bomb except that the rate of reaction is carefully controlled to avoid any explosive reaction. Since the material inside the reactor vessel is highly radioactive, it is absolutely necessary to contain it within a sealed system so that minimum radioactivity escapes outside. This is done by using very thick steel plates (10 to 12 inches) to construct the reactor vessel. This vessel acts as the primary containment for the radioactive material. Then, a thick concrete outer building (typically with $2 \mathrm{ft}$. to $4 \mathrm{ft}$. thick walls) is built to house the reactor. This building is also sealed from the outside and provides a secondary containment in case radioactive material escapes from the primary containment. There are miles and miles of pipes, many of which are used in back-up safety systems of the plant. Many of these may also carry radioactive fluids. There are hundreds of valves, pumps, compressors, electric motors etc. in the plant. Once a nuclear power plant is activated, several areas are sealed off, and human access to these areas is limited because of high levels of radioactivity. Remote controlled devices and cranes are used to transport radioactive material to these areas. Any malfunctioning of electro-mechanical systems, operating these remote controlled devices, can lead to very complex problems. Furthermore, the extensive network of pipes may spring leaks, valves and pumps may malfunction, electric cables in non-accessible highly radioactive areas may cause short circuits, battery packs, electric motors, and diesel generators may break down. Technically simple devices, such as pressure gauges and other indicator dials may not show proper reading due to hydraulic malfunctioning as has been known to happen. Mis-reading of data by plant operators may lead to wrong remedial measures causing possible disasters. In fact, nuclear power plants have so many complex sub-systems that many combinations of malfunctioning are possible, leading to serious accidents.

A major problem, in operating a nuclear plant, is the disposal and storage of the radioactive waste material produced by the plant. Around 20-30 tons of high-level wastes are produced per month per nuclear reactor. Several methods have been suggested for final disposal of high-level waste, including deep burial in stable geological structures, transmutation, and removal to space. So far, none of these methods have been implemented.

The main problem of nuclear plants is release of radioactivity. This is a serious concern for environment. It includes deterioration of radioactive waste containers due to radioactive and thermal effects and the consequential leakage and contamination of groundwater.

It is not required to rely on imagination to visualize the consequences of nuclear power plant accidents since such accidents have occurred in the recent past.

In March 2011 an earthquake and tsunami caused damage that led to explosions and partial meltdowns at the Fukushima I Nuclear Power Plant in Japan. Radiation levels at the stricken Fukushima I power plant have varied spiking up to $1,000 \mathrm{mSv} / \mathrm{h}$ (millisievert per hour), which is a level that can cause radiation sickness to occur at a later time following a one hour exposure. Significant release in emissions of radioactive particles took place following hydrogen explosions at three reactors, as technicians tried to pump in seawater to keep the uranium fuel rods cool, and bled radioactive gas from the reactors in order to make room for the seawater. Concerns about the possibility of a large scale radiation leak resulted in $20 \mathrm{~km}$ exclusion zone being set up around the power plant and people within the $20-30 \mathrm{~km}$ zone being advised to stay indoors.

The 1986 Chernobyl disaster in the Ukraine was the world's worst nuclear power plant accident. Estimates of its death toll are controversial and range from 4,056 to 985,000 . Large amounts of radioactive contamination were spread across Europe, and cesium and strontium contaminated many agricultural products, livestock and soil. The accident necessitated the evacuation of 300,000 people from Kiev, rendering an area of land unusable to humans for an indeterminate period. As radioactive materials decay, they release particles that can damage the body and lead to cancer, particularly cesium-137 and iodine-131. In the Chernobyl disaster, releases of cesium-137 contaminated land. Some communities were abandoned permanently. Thousands of people who drank milk contaminated with radioactive iodine developed thyroid cancer.

As it is seen that nuclear power plant can have nega- 
tive impact on the environment, Bangladesh needs to be careful. Since most citizens of Bangladesh children, women and men live within a 200-mile radius of the proposed Rooppur nuclear power plant. The disastrous effects of such proximal living to a nuclear plant are amply demonstrated in the case of those people living near Chernobyl. Any accident in the Rooppur power plant has the potential to adversely impact the lives of every citizen of Bangladesh and of future generations. So government should reconsider the RNPP (Rooppur power plant) Project and evaluate the project again for the future environmental effect.

\section{Conclusions}

Bangladesh is power hunger country. At present total demand of power is $5500 \mathrm{Mw}$ and total generation is $4200 \mathrm{Mw}$. So form the figure it is clear that it is essential to generate more power and for power generation more power stations is needed. But the considerable thing is the environmental concern. Most of the time during a power station project feasibility study of environment is not properly justified. So emphasis must be given to that and at the same time corruption must be controlled during project evaluation. Bangladesh government is trying to go through clean energy due its less effect of environment. Though it is still in research stage, government can not fulfill the recent energy crisis by clean energy. So it is high time for Bangladesh government to meet the recent energy crisis by environmental friendly power generation.

\section{REFERENCES}

[1] Country of Origin Effect in a Developing Country by Syed H Rahman, Page 1.

[2] Power Sector Reform in Bangladesh: Electricity Distribution System by M. S. Alam, E. Kabir, M. M. Rahman and M. A. K. Chowdhury.

[3] Load Shedding of Electricity in Bangladesh by Khaled Saifullah in www.freshclick.wordpress.com.

[4] Bangladesh: Power System Efficiency Improvement by Ministry of Power, Energy and Mineral Resources for Asian Development Bank (ADB) page10.

[5] Health and Environmental Impacts of Electricity Generation System: Procedures for Comparative Assessment by International Atomic Energy Agency, Page1.

[6] www.naturalgas.org/environment/naturalgas

[7] Environmental Impact of Power Generation by Royal Society of Chemistry, page1. 